American Journal of Biochemistry and Biotechnology 7 (3): 135-140, 2011

ISSN 1553-3468

(C) 2011 S. Ponkumar et al., This open access article is distributed under a Creative Commons Attribution (CC-BY) 3.0 license

\title{
Structural Analysis of DNA Interactions with Magnesium Ion Studied by Raman Spectroscopy
}

\author{
Ponkumar, S., P. Duraisamy and N. Iyandurai \\ Department of Physics, Thiruvalluvar Government Arts College, \\ Rasipuram-637 401, TamilNadu, India
}

\begin{abstract}
Problem statement: In the present study, FT Raman spectroscopy had been used to extend our knowledge about Magnesium ion - DNA interactions at various volume ratios (1:50, 1:20, 1:10 and 1:5). Approach: The analysis of FT Raman data supported the existence of structural specificities in the interaction and also the stability of DNA secondary structure. Results: Results from the Raman spectra clearly indicate that the interaction of Magnesium ion with DNA is mainly through the phosphate groups of DNA with negligible change of the B-conformation of DNA at all the volume ratios studied. For example, band at $1079 \mathrm{~cm}^{-1}$ is assigned to the symmetrical stretching vibration of the nucleic acid phosphodioxy (PO-2) group. This band in the order $1079 \rightarrow 1075 \rightarrow 1070 \rightarrow 1066 \rightarrow 1063 \mathrm{~cm}^{-1}$ at all Magnesium ion DNA concentrations studied. Similarly, Raman band at $845 \mathrm{~cm}^{-1}$ due to antisymmetrical phosphodiester (O-P-O) stretching of DNA. Conclusion: Magnesium ion interaction with the DNA phosphate is weak in comparison to interactions with the bases. On the other hand, the Raman signature of B-DNA is largely unperturbed by magnesium ion, suggesting much weaker interactions.
\end{abstract}

Key words: Stretching vibration, B conformation, FT Raman data, FT Raman spectroscopy, Raman spectra, volume ratios, nucleic acids, magnesium deficiency, stacking interactions

\section{INTRODUCTION}

Metal ions are essential for the biological activity of nucleic acids, as well as the characteristics that can prove harmful, result from the interaction of metals to nucleic acids. It is for this reason that studies of the effects of metal interaction in nucleic acids are very much important. Magnesium deficiency causes renal complications. The appearance of several diseases is related to its depletion in the human body (Anastassopoulou and Theophanides, 2002). The binding of metals by nucleosides and nucleotides has been investigated for a number of years. Because of recent observations that some metal ions cause chromosome damage and consequently is mutagenic, there is renewed interest in the binding of heavy metals to polynucleotide. Interestingly, binding of Magnesium ions to the backbone phosphate groups may play role in enhancing the lifetime of the open state of the DNA base pairs, thus accelerating the regulatory process of genetic information transfer. The alkaline earth metals also play the role of stabilizing the double helix by neutralization of the negative changes on the phosphate groups. Remarkably, extreme stabilization by metal ions can lead to rather adverse result, i.e., the mis-pairing of bases. Since the correct propagation of the genetic code requires the correct complementary base pairing, mis-pairing can lead to error (Printz and Hippel, 1965).

In view of this, the objective of the present study is to characterize the structural changes that DNA undergoes in the presence of Magnesium ions. One of the methods of promise to provide information on binding sites, stacking interactions and conformation, is vibration spectroscopy, particularly FT Raman spectroscopy. Here the FT Raman spectroscopy has been used to

Corresponding Author: Iyandurai, N., Department of Physics, Thiruvalluvar Government Arts College, Rasipuram637401, TamilNadu, India 
analyze the effect of Magnesium ion on DNA at various volume ratios.

\section{MATERIALS AND METHODS}

Highly polymerized calf-thymus DNA sodium salt $\left(6.2 \%\right.$ sodium content, $13 \% \mathrm{H}_{2} \mathrm{O}$ content $)$ and were purchased from Sigma Chemical Co. DNA was deproteinated by the addition of $\mathrm{CHCl} 3$ and isoamyl alcohal in $\mathrm{NaCl}$ solution. Sodium-DNA was dissolved in $50 \mathrm{mM} \mathrm{NaCl}(\mathrm{pH} 7.20)$ at $5^{\circ} \mathrm{C}$ for $24 \mathrm{~h}$ with occasional stirring to ensure the formation of a homogeneous solution.

The appropriate amount of magnesium ion (50 $\mathrm{mM}$ ) was prepared in distilled water and added drop wise to the DNA solution to attain the desired Magnesium ion - DNA (1:50, 1:20, 1; 10 and 1:5), volume ratios. The $\mathrm{pH}$ of all the solutions was adjusted at 7 .

FT Raman measurements: FT Raman spectra were recorded in a Bruker Equimox 55 FT spectrometer supplied with a Raman module. Spectra are applied at the spectral resolution of $2 \mathrm{~cm}^{-1}$, using excitation radiation wave number at $1064 \mathrm{~nm}$ from Nd-YAG laser working at $500 \mathrm{~mW}$. We used a standard quartz cell for liquids (1-cm section) where approximately $1 \mathrm{~mL}$ of the solutions was placed. Backscattering collection of the Raman radiation was performed using a mirror behind the cell and minimum of 2000 scans were accumulated in all case to enhance the signal-to-noise ratios. Raman spectra were recorded between 600 and $1800 \mathrm{~cm}^{-1}$. The Raman spectra of Magnesium ion-
DNA complexes at various volume ratios (1:50, 1:20,1:10 and 1:5) are recorded.

\section{RESULTS AND DISCUSSION}

Analysis of FT Raman spectroscopic data: The FT Raman spectra of calf-thymus DNA and Magnesium ion - DNA complexes (1:50, 1:20, 1:10 and 1:5 volume ratios) are displayed in Fig. 1 and Table 2 shows the relevant wave numbers for the complete range of concentrations studied.

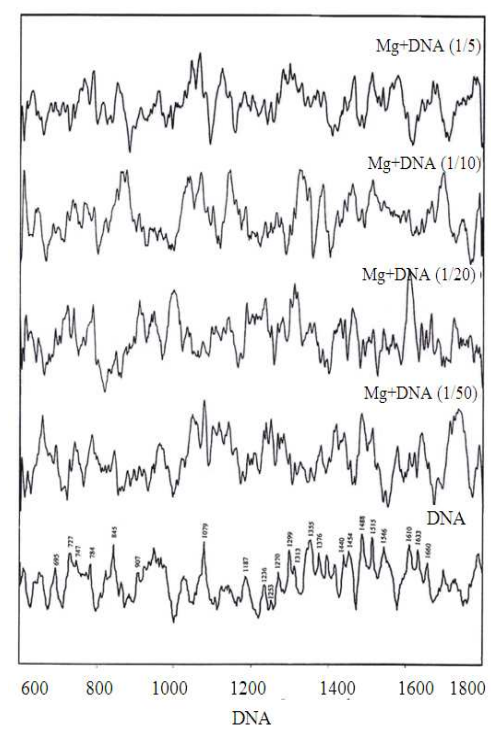

Fig. 1: FT Raman spectrum of calf thymus DNA and Magnesium ion - DNA complexes (1:50, 1:20, 1:10 and 1:5 volume ratios)

Table 1: Wave numbers for the complete range of concentrations studied

\begin{tabular}{|c|c|c|c|c|c|}
\hline DNA & $\operatorname{Mg}+$ DNA $(1: 50)$ & $\operatorname{Mg}+\operatorname{DNA}(1: 20)$ & Mg+DNA $(1: 10)$ & Mg+DNA (1:05) & Assignments \\
\hline 695 & 693 & 690 & 687 & 688 & Guanine [C1'-N9 stretching] \\
\hline 727 & 727 & 723 & 722 & 722 & $\mathrm{dA}[\mathrm{C} 1$ ' -N9 stretching $]$ \\
\hline 747 & 740 & 738 & 736 & 736 & dT[N-H out- of- plane bending] \\
\hline 784 & 786 & 789 & 790 & 790 & dC, dT, O-P-O sym.str mode \\
\hline 845 & 845 & 848 & 848 & 850 & $\mathrm{O}-\mathrm{P}-\mathrm{O}$ asym.str mode \\
\hline 907 & 908 & 908 & 909 & 909 & Deoxyribose \\
\hline 1079 & 1075 & 1070 & 1066 & 1063 & $\mathrm{PO}_{2}^{-}$sym. str \\
\hline 1187 & 1187 & 1185 & 1183 & 1178 & $\mathrm{dT}\left[\mathrm{C} 5-\mathrm{CH}_{3}\right.$ bond and in-plane ring stretching $]$ \\
\hline 1236 & 1236 & 1235 & 1233 & 1230 & $\mathrm{dC}$ [in plane ring str] \\
\hline 1253 & 1250 & 1250 & 1248 & 1247 & $\mathrm{dC}[$ in-plane ring stretching $]$ \\
\hline 1270 & 1267 & 1265 & 1262 & 1264 & $\mathrm{dC}[$ in-plane str. mode $]$ \\
\hline 1299 & 1298 & 1298 & 1297 & 1296 & $\mathrm{dC}, \mathrm{dT}[$ ring stretching] \\
\hline 1313 & 1310 & 1310 & 1308 & 1306 & dG[imidazole ring coupled with(c8-N9) str] \\
\hline 1355 & 1352 & 1349 & 1347 & 1343 & $\mathrm{dG}[\mathrm{C} 2=\mathrm{N} 3-\mathrm{C} 4=\mathrm{C} 5-\mathrm{N} 7=\mathrm{C} 8$ triene moiety $]$ \\
\hline 1376 & 1379 & 1382 & 1382 & 1384 & $\mathrm{dT}\left[\mathrm{C} 5-\mathrm{CH}_{3}\right.$ str, $\mathrm{C} 6-\mathrm{H}$ in-plane bending], dA \\
\hline 1440 & 1440 & 1440 & 1438 & 1436 & $\mathrm{dT}\left[\mathrm{C}^{\prime}-\mathrm{H}_{2}\right.$ deformation $]$ \\
\hline 1454 & 1455 & 1459 & 1460 & 1463 & dT[C5- $\mathrm{CH}_{3}$ def., N3-H in-plane bending] \\
\hline 1488 & 1486 & 1486 & 1485 & 1483 & $\mathrm{dG}, \mathrm{dA}[\mathrm{N} 7-\mathrm{C} 8$ stretching] \\
\hline 1515 & 1513 & 1513 & 1512 & 1510 & $\mathrm{dA}$ [ring str] \\
\hline 1546 & 1546 & 1543 & 1541 & 1538 & $\mathrm{dG}$ [imidazole ring and C6 moiety] \\
\hline 1610 & 1608 & 1608 & 1607 & 1603 & $\mathrm{dC}$ [ring str] \\
\hline 1633 & 1636 & 1638 & 1640 & 1640 & $\mathrm{dC}$ [Carbonyl C2=Ostr mode] \\
\hline 1660 & 1660 & 1665 & 1666 & 1668 & dT [in-phase stretching] \\
\hline
\end{tabular}


The FT Raman spectra of the Magnesium ion - DNA at various volume ratios show wave number shifts, indicating that interactions are present without condensation.

\section{Interpretation of FT Raman spectra of solutions} in water: Raman bands in the $600-800 \mathrm{~cm}^{-1}$ regions occur due to $\mathrm{C}-\mathrm{C}$ and $\mathrm{C}-\mathrm{N}$ bonds of the base residues, which stretch and contract in phase. Such a ring breathing vibrations invariably give often the most intense Raman bands in the spectrum (Thomas, 1970).

The Raman band observed at $695 \mathrm{~cm}^{-1}$ of calf thymus DNA is assigned to breathing motion of the guanine coupled through the $\mathrm{C} 1$ '-N9 glycoside bond to a deoxyribose vibration (Benevides et al., 1984). The $695 \mathrm{~cm}^{-1}$ band also characterizes the C2'-endo/anti conformation of B-DNA in aqueous solution (Kiefer, 2007). In Magnesium ion - DNA spectrum the $695 \mathrm{~cm}^{-1}$ band of metal free DNA shifts in the order $695 \rightarrow 693 \rightarrow 690 \rightarrow 687 \rightarrow 688$ $\mathrm{cm}^{-1}$ at all the concentrations studied. This result indicate that in the presence of Magnesium ions the B-form structure is melted and the population of $\mathrm{dG}$ conformers changes from predominantly $\mathrm{C} 2$ '-endo/anti to a mixture of C2'-endo/anti and C2'-endo/syn conformers. Duguid et al. (1993) observed similar spectral changes in the study of Raman spectroscopy of DNA - metal complexes.

The sugar coupled adenine vibration observed at $727 \mathrm{~cm}^{-1}$ in metal free DNA is observed at 727 , 723 and $722 \mathrm{~cm}^{-1}$ in Magnesium ion -DNA complexes, which may be due to strong interaction of the bases with one another or with the metal ions. Harada and Takeuchi, (1986) observed similar results in the Raman spectra of tryptophan and related compounds. The $\mathrm{N}-\mathrm{H}$ out-of plane bending vibration of thymine near $747 \mathrm{~cm}^{-1}$ of metal free DNA identifies the C2' endow/anti conformers of dT (Rush and Peticolas, 1995). In Magnesium ion-DNA complexes, the $747 \mathrm{~cm}^{-1}$ band of DNA shifts to lower frequency in the order $747 \rightarrow 740 \rightarrow 738 \rightarrow 736 \mathrm{~cm}^{-1}$, which indicates that the tensional rotations about the glycosyl bond become more flexible in Magnesium ion - DNA complexes. Duguid et al. (1996) have observed similar results.

The $784 \mathrm{~cm}^{-1}$ band is the composite of two major bands, one due to the cytosine ring breathing mode (Tajmir-Riahi et al., 1988) and the other due to phosphosiester symmetric stretching vibration (Dam et al., 2002). The cytosine vibration is sensitive to deputation exocyclic substitution while the phosphodiester vibration is less sensitive to deputation. The thymidine vibration, which involves both significant contribution from deoxyribose ring and dominant contribution from the thymine vibration, is sensitive to C2' deuteration (Tsuboi et al., 1997). The appearance of the cytosine vibration at higher frequency at 790 $\mathrm{cm}^{-1}$ in Magnesium ion -DNA (higher concentration) spectrum indicates that Magnesium ions react readily with the $\mathrm{N} 3$ atom of cytosine.

Raman bands in the $750-850 \mathrm{~cm}^{-1}$ spectral intervals have been assigned to vibrations which involve a large contribution from oxygenphosphorous stretching of the phosphodiester (O-PO) linkages (Ruiz-Chica et al., 2001) and oxygenphosphorous stretching of the phophodioxy $\left(\mathrm{PO}_{2}\right)$ group (Nafisi et al., 2008). Because of obvious coupling between sugar and phosphate groups, these bands are extraordinarily sensitive to the nucleic acid backbone conformation and provide a firm empirical basis for DNA conformational analysis (Nafisi et al., 2008). FT-Raman spectrum of calf thymus DNA exhibits a band at $845 \mathrm{~cm}^{-1}$ due to ant symmetrical phosphodiester (O-P-O) stretching (Ruiz-Chica et al., 2001). This band is considered as diagnostic B conformation (Nafisi et al., 2008). The $845 \mathrm{~cm}^{-1}$ frequency originates from vibrations associated with the 3, 5, phosphodiester network (C-O-P-O-C). The 845 $\mathrm{cm}^{-1}$ band is shifted in the order $845 \rightarrow 848 \rightarrow 850$ $\mathrm{cm}^{-1}$ at all the Magnesium ion - DNA complex ratios studied. This is an indicative of a wide distribution of torsion angles in the backbones of Magnesium ion - DNA. Thomas III Rush and Warner, 1995 pragmatic show the matching results in an ab initio transform calculation of resonance Raman spectra of uracil, 1-methyluracil and 5methyluracil.

Raman band at $907 \mathrm{~cm}^{-1}$ have been assigned to stretching vibrations of the deoxyribose rings for DNA (Prescutt et al., 1984). Their shifts upon Magnesium ion complication indicate contribution of the sugar moieties in the interaction. Also the Raman band assigned to the symmetrical stretching vibration of the nucleic acid phosphodiozy $\left(\mathrm{PO}_{-}\right)$ group (Guan and Thomas Jr., 1996) is observed at $1079 \mathrm{~cm}^{-1}$ in $\mathrm{H}_{2} \mathrm{O}$ solution. The ant symmetrical stretching vibration of the phosphodioxy group $(\mathrm{PO}-2)$ is expected near $1200 \mathrm{~cm}^{-1}$. The Raman scattering of ant symmetrical stretching vibration is characteristically very weak, although it generates intense infrared absorption (Aubrey et al., 1992). At all Magnesium ion- DNA concentrations studied, the $1079 \mathrm{~cm}^{-1}$ band of metal free DNA shifts to lower frequency in the order $1079 \rightarrow$ 
$1075 \rightarrow 1070 \rightarrow 1066 \rightarrow 1063 \mathrm{~cm}^{-1}$. This effect is due to interaction of Magnesium ions with the ionized PO-2 groups through water molecules (outer-space interactions or, more generally, formation of water-separated in pairs). The effect of the metal action in this $\mathrm{Mg}^{2+}----\mathrm{O}(\mathrm{H})-\mathrm{H}----\mathrm{O}_{2} \mathrm{P}$ type of aggregate is to increase the acidity of the water molecules and to strengthen the hydrogen bond affecting the phosphate group, causing a decrease in frequency of the symmetric stretch PO2 vibration (Toyama et al., 1993).

Raman bands in $1180-1600 \mathrm{~cm}^{-1}$ region of the Raman spectrum arises primarily from conjugated $\mathrm{CC}, \mathrm{CN}$ and $\mathrm{CO}$ in-plane stretching modes of the urine and pyramiding bases in which adjoining bonds stretch with $180^{\circ}$ phase difference (Aida et al., 1997). These Raman bands have the potential for diagnosis of nucleic acid secondary structure.

The FT-Raman spectrum of DNA in $\mathrm{H}_{2} \mathrm{O}$ solution exhibits bands at 1187 and $1236 \mathrm{~cm}^{-1}$. These two bands have been assigned to vibrations involving stretching of exocyclic $\mathrm{C} 5-\mathrm{CH}_{3}$ bond of thymine and in-plane ring vibrations of cytosine (Rush and Peticolas, 1995). In the presence of Magnesium ions the $1187 \mathrm{~cm}^{-1}$ thymine band of metal free DNA shifts in the order $1187 \rightarrow 1185$ $\rightarrow 1183 \rightarrow 1178 \rightarrow 1177 \mathrm{~cm}^{-1}$, the lower frequency shift is due to a decrease in electron delocalization in the thymine bases as DNA melts and the metal ion interaction with the melted structure. Duguid et al. (1993) have observed similar frequency shift during thermal denaturation of calf-thymus DNA. Similarly the $1236 \mathrm{~cm}^{-1}$ band shifts in the order $1236 \rightarrow 1235 \rightarrow 1233 \rightarrow 1230$ in the presence of Magnesium ions. These effects are attributed to partial disruption of A-T base pairs and metal binding at N3 atom of thymine and cytosine.

Three bands are observed in the FT-Raman spectrum of DNA at 1253,1270 and $1299 \mathrm{~cm}^{-1}$. The first two bands are due to ring stretching vibration of cytosine, while the $1299 \mathrm{~cm}^{-1}$ band is due to ring stretching vibration of both cytosine and thymine (Spiker and Levin, 1975). All these bands shifted downwards to several $\mathrm{cm}^{-1}$ in presence of Magnesium ions indicating interactions are present. The FT-Raman spectrum of DNA shows a band $1313 \mathrm{~cm}^{-1}$ due to guanine imidazole ring coupled with C8-N9 stretching vibration (Iyandurai and Sarojini, 2009). This band is shifted in the order $1313 \rightarrow 1310 \rightarrow 1308 \rightarrow 1306$ $\mathrm{cm}^{-1}$ upon complex formation with Magnesium ions. Similarly, Raman band observed at $1355 \mathrm{~cm}^{-1}$ band in $\mathrm{H}_{2} \mathrm{O}$ solution has been assigned to a guanine imidazole ring mode of the $\mathrm{C} 2=\mathrm{N} 3-\mathrm{C} 4=$ $\mathrm{C} 5-\mathrm{N} 7=\mathrm{C} 8$ triene moiety (Iyandurai and Sarojini,
2009) which shifts in the order $1355 \rightarrow 1352 \rightarrow$ $1349 \rightarrow 1347 \rightarrow 1343 \mathrm{~cm}^{-1}$ at all the Magnesium ion -DNA complexes studied. The results suggest partial denaturation of DNA in the presence of metal ions and metal ion binding with the denatured structure. Duguid et al. have made similar observations in Raman spectra of calf-thymus DNA in the presence of divalent metal ions during thermal denaturation (Duguid et al., 1993).

The intense band at $1376 \mathrm{~cm}^{-1}$ is assigned to in-plane ring vibration (Iyandurai and Sarojini, 2009) and C6-H in plane bend vibration of thymine. This normal mode also involves the exocylic $\mathrm{C} 5-\mathrm{CH}_{3}$ group of thymine and is sensitive to the methyl group environment. Adenine also contributes to this intense band (Po et al., 2007). This band shifts to higher frequency side in the presence of Magnesium ion indicating metal binding at $\mathrm{N} 3$ atom thymine and adenine. Raman band at $1440 \mathrm{~cm}^{-1}$ has been assigned to $\mathrm{C}^{\prime}-\mathrm{H}_{2}$ deformation of thymine. This band is shifted to $1436 \mathrm{~cm}^{-1}$ at higher Magnesium ion - DNA concentration. This shows minor $\mathrm{C}^{\prime}-\mathrm{H}_{2}$ deformation of thymine. The Raman band measured at $1454 \mathrm{~cm}^{-1}$ in the Raman spectrum of DNA has been assigned to the deoxyribose moieties (Iyandurai and Sarojini, 2009). They correspond to ethylene bending modes, although they should also have some contributions from adenine vibrations. This band shifts in the order $1454 \rightarrow 1455 \rightarrow 1459 \rightarrow 1460 \rightarrow 1463 \mathrm{~cm}^{-1}$ at all Magnesium ion -DNA complexes studied.

The $1488 \mathrm{~cm}^{-1}$ band of FT-Raman spectrum has been assigned to a vibration involving a large displacement of $\mathrm{N} 7$ and $\mathrm{C} 8$ atoms of urine (guanine and adenine) (Po et al., 2007). The guanine contribution is greater, approximately threefold larger than that of adenine. The band has great diagnostic value, both as a monitor of deuterium exchange kinetics of the urine $\mathrm{C} 8 \mathrm{H}$ group and as an indicator of urine N7 hydrogen bonding interactions. The present result shows metal ion binding at N7 position of guanine through water molecule. The effect of the metal ion in this $\mathrm{Mg}^{2+}-\mathrm{O}(\mathrm{H})--\mathrm{H}--\mathrm{N} 7$ type of aggregate is to increase the strength of the hydrogen bonds between the N7 of guanine and hydrogen of water, causing a decrease in frequency of the $1488 \mathrm{~cm}^{-1}$ band.

The FT-Raman spectrum of DNA shows a band at $1515 \mathrm{~cm}^{-1}$ due to adenine (Bruce, 2007) ring stretching vibration and the band observed at $1546 \mathrm{~cm}^{-1}$ in $\mathrm{H}_{2} \mathrm{O}$ solution is due to guanine imidazole ring and C6 moiety (Kiefer and Beckmann, 1984). Upon higher Magnesium ion 
concentration this band exhibits shift in the order $1515 \rightarrow 1510$ and $1546 \rightarrow 1538 \mathrm{~cm}^{-1}$ indicating guanine contributes more than an adenine.

The region $1600-1750 \mathrm{~cm}^{-1}$ in Raman spectrum is often called the "double-bond region" contains bands due to stretching vibrations of double bonds including carbonyl groups of $\mathrm{C}, \mathrm{G}$ and $\mathrm{T}$. Also the bands in this region include contributions from in-plane deformations of $\mathrm{NH}$ groups of $\mathrm{G}$ (amino and amino), $\mathrm{C}$ (amino) and $\mathrm{T}$ (amino). The $1610 \mathrm{~cm}^{-1}$ band of metal free DNA due to ring stretching vibration of cytosine shifts to lower frequency in the order $1610 \rightarrow 1608 \rightarrow 1607 \rightarrow 1603 \mathrm{~cm}^{-1}$ in Magnesium ion -DNA complexes. This result indicates metal binding at $\mathrm{N} 3$ atom of cytosine. The $1630 \mathrm{~cm}^{-1}$ band of metal free DNA assigned to $\mathrm{C} 2=\mathrm{O}$ stretching and $\mathrm{NH}_{2}$ scissoring vibration (Moreira et al., 2008) of cytosine shifts to higher frequency near $1640 \mathrm{~cm}^{-1}$ in Magnesium ion -DNA (1:5 volume ratio) complex spectrum. Ordinarily, the frequency of a $\mathrm{C}=\mathrm{O}$ stretching vibration increases with decreasing hydrogen-bonded strength (Tomlinson and Peticolas, 1970). The elevated C2 $=\mathrm{O}$ frequency in the complex spectrum reflects carbonyls less strongly hydrogen bonded in the Magnesium ion - DNA complex than in the metal-free DNA. The Raman band observed at $1660 \mathrm{~cm}^{-1}$ in metal free DNA, due to thymine inphase stretching of $\mathrm{C} 5-\mathrm{C} 6, \mathrm{C} 2=\mathrm{O}$ and $\mathrm{C} 4=\mathrm{O}$ vibrations exhibits small shift in the order $1660 \rightarrow 1665 \rightarrow 1666 \rightarrow 1668 \quad \mathrm{~cm}^{-1}$ in Magnesium ion-DNA complexes indicating unshackling of the A-T base pairs.

\section{CONCLUSION}

The FT-Raman spectra of DNA with Magnesium ion interpret that the ion bind to the phosphate groups of DNA, with negligible change of the B-conformation of DNA. The ribose moieties of all Magnesium ion-DNA complexes have a mixture of $\mathrm{C}^{2}$ '-endo and $\mathrm{C} 3$ 'endo sugar bucker. Magnesium ions interact (via $\mathrm{H}_{2} \mathrm{O}$ ) with acceptor sites on the urine (N7) rings and make tensional rotations about the glycosyl bond more flexible. A notable exception is an extensive perturbation by magnesium ions on pyrimidine (N3) ring. Various bands assigned to urine and pyramiding vibrations in the region 1200-1600 $\mathrm{cm}^{-1}$ are sensitive to base unshackling (elimination of hypo chromic effect) in Magnesium ion - DNA complexes.

\section{REFERENCES}

Aida, M., M. Kaneko, M. Dupuis, T. Ueda and K. Ushizawa et al., 1997. Vibrational modes in thymine molecule from an ab initio MO calculation. Spectrochimica Acta Part A: Mol. Biomol. Spectroscopy, 53: 393-407. DOI: 10.1016/S1386-1425(96)01811-2

Anastassopoulou, J. and T. Theophanides, 2002. Magnesium-DNA interactions and the possible relation of magnesium to carcinogenesis. Irradiation and free radicals, Crit. Rev. Oncol. Heamatol., 42: 79-91. PMID: 11923070

Aubrey, K.L., S.R. Casjens, G.J. Thomas Jr., 1992. Secondary structure and interactions of the packaged dsDNA genome of bacteriophage P22 investigated by Raman difference spectroscopy. Biochemistry, 31: 11835-11842. PMID: 1445916

Benevides, J.M., A.H.J., Wang, G.A.V.D. Marel, J.H.V. Boom and A. Rich et al., 1984. The Raman spectra of left-handed DNA oligomers incorporating adenine-thymine base pairs, Nucl. Acids Res., 12: 5913-5925. DOI: 10.1093/nar/12.14.5913

Bruce, C., 2007. FT-Raman spectroscopy: A catalyst for the raman explosion? J. Chem. Educ., 84: 75-75. DOI: 10.1021/ed084p75

Dam, L.V., N. Korolev and L. Nordenskiold, 2002. Polyamine-nucleic acid interactions and the effects on structure in oriented DNA fibers. Nucl. Acids Res. 30: 419-428. DOI: 10.1093/nar/30.2.419

Duguid, J., V.A. Bloomfield, J. Benevides and G.J. Thomas Jr., 1993. Raman spectroscopy of DNA-metal complexes. I. Interactions and conformational effects of the divalent cations: $\mathrm{Mg}, \mathrm{Ca}, \mathrm{Sr}, \mathrm{Ba}, \mathrm{Mn}, \mathrm{Co}, \mathrm{Ni}, \mathrm{Cu}, \mathrm{Pd}$ and $\mathrm{Cd}$. Biophys. J., 65: 1916-1928. PMCID: PMC1225927

Guan, Y. and G.J. Thomas Jr., 1996. Vibrational analysis of nucleic acids. III. Conformationdependent Raman markers of the phosphodiester backbone modeled by dimethyl phosphate. J. Mol. Structure, 379: 31-41. DOI: 10.1016/0022-2860(95)09059-2.

Harada, I., T. Miura and H. Takeuchi, 1986. Origin of the doublet at 1360 and $1340 \mathrm{~cm}-1$ in the Raman spectra of tryptophan and related compounds. Spectrochimica Acta Part A Mol. Spectroscopy, 42: 307-312. DOI: 10.1016/0584-8539(86)80193-3 
Iyandurai, N. and R. Sarojini, 2009. Selenomethionine induced changes on the binding of spermine with DNA: A study by fourier transform raman and fourier transform infra red spectroscopy. Int. J. Pharmacol., 5: 126-136. DOI: 10.3923/ijp.2009.126.136

Kiefer, W. and A. Beckmann, 1984. Non-linear coherent Raman spectroscopy. J. Mol. Structure, 113: 83-99. DOI: 10.1016/00222860(84)80135-0

Kiefer, W., 2007. Recent advances in linear and nonlinear raman spectroscopy I. J. Raman Spectroscopy, 38: 1538-1553. DOI: 10.1002/jrs.1902

Moreira, L.M., L. Silveira Jr., F.V. Santos, J.P. Lyon and R. Rocha et al., 2008. Raman spectroscopy: A powerful technique for biochemical analysis and diagnosis. Spectroscopy, 22: 1-19. DOI: 10.3233/SPE2008-0326

Nafisi, S., M. Hashemi, M. Rajabi and H.A. Tajmir-Riahi, 2008. DNA adducts with antioxidant flavonoids: Morin, apigenin and naringin. DNA Cell Biol., 27: 433-442. DOI: 10.1089/dna.2008.0735

Po, A., R.A. Bitar, K. Yassoyama, H. Martinho and A.M. Santo et al., 2007. Study of normal colorectal tissue by FT-Raman spectroscopy. analytical Bioanalytical Chem., 387: 16431648. DOI: 10.1007/s00216-006-0819-1

Printz, M.P. and P.H.V. Hippel, 1965. Hydrogen exchange studies of DNA structure. Proc. Nat. Acad. Sci. U. S. A., 53: 363-370. PMID: 14294070

Ruiz-Chica, A.J., A.R. Khomutov, M.A. Medina, F. Sanchez-Jimenez and F.J. Ramirez, 2001. Interaction of DNA with an aminooxy analogue of spermidine-an FT-IR and FTRaman approach. J. Mol. Structure, 565-566: 253-258. DOI: $10.1016 / \mathrm{S} 0022-$ 2860(00)00842-5

Rush, T.I. and W.L. Peticolas, 1995. Ab Initio transform calculation of resonance raman spectra of uracil, 1-Methyluracil and 5Methyluracil. J. Phys. Chem., 99: 1464714658. DOI: $10.1021 / \mathrm{j} 100040 \mathrm{a} 012$
Spiker Jr., R.C. and I.W. Levin, 1975. Raman spectra and vibrational assignments for dipalmitoyl phosphatidylcholine and structurally related molecules. Biochimica Biophys. Acta, 388: 361-373. PMID: 1137716

Tajmir-Riahi, H.A., M. Langlais and R. Savoie, 1988. A laser Raman spectroscopic study of the interaction of calf-thymus DNA with $\mathrm{Cu}(\mathrm{II})$ and $\mathrm{Pb}$ (II) ions: Metal ion binding and DNA conformational changes. Nucleic Acids Res., 16: 751-762. DOI: 10.1093/nar/16.2.751

Thomas Jr., G.J., 1970. Raman spectral studies of nucleic acids: III. Laser-excited spectra of ribosomal RNA. Biochim. Biophys. Acta (BBA)-Nucleic Acids Protein Synthesis, 213: 417-423. DOI: 10.1016/00052787(70)90049-3

Thomas Jr., G.J., J.M. Benevides, S.A. Overman, T. Ueda and K. Ushizawa et al., 1995. Polarized Raman spectra of oriented fibers of A DNA and B DNA: Anisotropic and isotropic local Raman tensors of base and backbone vibrations. Biophys. J., 68: 1073-88. PMID: 7756527

Tomlinson, B.L. and W.1. Peticolas, 1970. Conformational dependence of Raman scattering intensities in polyadenylic acid. J Chem. Phys., 52: 2154-2156. PMID: 5445421

Toyama, A. Y. Takino, H. Takeuchi and I. Harada, 1993. Ultraviolet resonance Raman spectra of ribosyl $\mathrm{C}\left(1^{\prime}\right)$-deuterated purine nucleosides: evidence of vibrational coupling between purine and ribose rings. J. Am. Chem. Soc., 115: 11092-11098. DOI: 10.1021/ja00077a005

Tsuboi, M., M. Komatsu, J. Hoshi, E. Kawashima and T. Sekine et al., 1997. Raman and infrared spectra of (2‘S)-[2‘- $\left.{ }^{2} \mathrm{H}\right]$ thymidine: Vibrational coupling between deoxyribosyl and thymine moieties and structural implications. J. Am. Chem. Soc., 119: 2025-2032. DOI: 10.1021/ja962676t 